\title{
The Effects of Vitamin D Level on Bone Lesions and Prognostic Factors in Multiple Myeloma
}

\author{
Multipl Miyelomda D Vitamini Düzeyinin Kemik Lezyonları ve \\ Prognostik Faktörler Üzerine Etkileri \\ (D) Gülden Sincan, (D) Fuat Erdem
}

Atatürk University Faculty of Medicine, Department of Hematology, Erzurum, Turkey

Keywords

Lytic bone lesion, multiple myeloma, prognostic factors, vitamin D level

Anahtar Kelimeler

Litik kemik lezyonu, multipl miyelom, prognostik faktörler, D vitamini düzeyi

Received/Geliş Tarihi : 20.12 .2020

Accepted/Kabul Tarihi : 26.03.2021

doi:10.4274/meandros.galenos.2021.94557

Address for Correspondence/Yazışma Adresi: Gülden Sincan MD,

Atatürk University Faculty of Medicine, Department of Hematology, Erzurum, Turkey

Phone : +90 5052724264

E-mail : guldensincan@gmail.com

ORCID ID: orcid.org/0000-0002-7671-7628

(C) Meandros Medical and Dental Journal, Published by Galenos Publishing House.

This is article distributed under the terms of the

Creative Commons Attribution NonCommercial 4.0

International Licence (CC BY-NC 4.0).

\begin{abstract}
Objective: Several studies have found that low vitamin D levels are associated with an increased risk of hematologic malignancies and a poor prognosis. In this study, we investigated the relationship between 25-hydroxyvitamin D levels and bone lesions as well as prognostic factors in patients with multiple myeloma. Materials and Methods: We evaluated 184 people who had just been diagnosed with multiple myeloma. Complete blood count, biochemical parameters, serum 25-hydroxyvitamin D [25(OH)D] level, presence of lytic bone lesion and fracture, and disease stage were all recorded. The patients were divided into three groups based on their 25(OH)D levels: deficient $(<20 \mathrm{ng} / \mathrm{mL})$, insufficient $(20-29 \mathrm{ng} /$ $\mathrm{mL})$, and normal ( $\geq 30 \mathrm{ng} / \mathrm{mL})$. SPSS-21 was used to perform statistical analyses. Results: The $25(\mathrm{OH}) \mathrm{D}$ was deficient in 121 patients $(65.8 \%)$, insufficient in 28 patients (15.2\%), and normal in 35 patients (19\%). Age, presence of lytic bone lesion and bone fracture, plasma cell rate in bone marrow, and stage of disease $(p=0.02 ; p=0.01 ; p=0.007 ; p=0.02$, respectively) all differed significantly between these groups. Patients with normal 25(OH)D levels had lower risk of lytic bone lesion and fracture. Furthermore, deficiency and insufficiency of $25(\mathrm{OH}) \mathrm{D}$ had a negative impact on disease stage, and advanced disease stage is a poor prognostic parameter for multiple myeloma. Conclusion: Patients with normal 25(OH)D levels have a lower risk of lytic bone lesion and vertebral fracture. The stage of the disease is influenced by $25(\mathrm{OH}) \mathrm{D}$ deficiency and insufficiency. Therefore, early detection and treatment of $25(\mathrm{OH})$ $\mathrm{D}$ deficiency and insufficiency in patients with multiple myeloma may reduce mortality and morbidity rates.
\end{abstract}

Öz

Amaç: Birkaç çalışma, düşük D vitamini düzeyinin, hematolojik malignitelerin artmış insidansı ve kötü prognozu ile ilişkili olduğunu bildirmiştir. Biz bu çalışmada multipl miyelomlu hastalarda, 25-hidroksivitamin D [25(OH)D] düzeyi ile kemik lezyonları ve prognostik faktörler arasındaki ilişkiyi araştırdık. Gereç ve Yöntemler: Yeni tanı almış 184 multipı miyelom hastası değerlendirildi. Tam kan sayımı, biyokimyasal parametreler, serum 25(OH)D düzeyi, litik kemik lezyonu ve kırık varlığı, hastalık evresi kaydedildi. Hastalar 25(OH)D düzeyine göre 3 gruba ayrıldı; eksik $(<20 \mathrm{ng} / \mathrm{mL})$, yetersiz $(20-29 \mathrm{ng} / \mathrm{mL})$ ve normal ( $\geq 30 \mathrm{ng} / \mathrm{mL}$ ). İstatistiksel değerlendirmeler SPSS-21 programı ile yapıldı. 
Bulgular: 25(OH)D düzeyi 121 hastada (\%65,8) eksik, 28 hastada yetersiz (\%15,2) ve 35 hastada (\%19) normaldi. Bu gruplar arasında yaş, litik kemik lezyonu ve kırık varlığı, kemik iliğinde plazma hücre oranı ve hastalık evresi açısından anlamlı fark vardı (sırasıyla $p=0,02, p=0,01, p=0,007, p=0,02$ ). 25(OH)D düzeyi normal olan hastalarda litik kemik lezyonu ve kırık daha azdı. Ek olarak; 25(OH)D eksikliği ve yetersizliği hastalığın evresini olumsuz etkiledi ve hastalığın ileri evresi multipl miyelom için kötü prognostik parametredir. Sonuç: 25(OH)D düzeyi normal olan hastalarda litik kemik lezyonu ve kemik kırığı daha az görülür. 25(OH)D eksikliği ve yetersizliği hastalığın evresini olumsuz etkiler. Bu nedenle; 25(OH)D eksikliği ve yetersizliğinin erken tespiti ve tedavisi multipl miyelomlu hastalarda mortaliteyi ve morbidite oranını azaltabilir.

\section{Introduction}

Vitamin D promotes calcium absorption from the intestine and provides sufficient serum calcium and phosphate concentrations for mineralization of the bones. Vitamin D deficiency mainly causes loss of bone density and it can contribute to osteoporosis and bone fractures. In addition; low vitamin D level is associated with cardiovascular diseases, solid organ and hematological cancers, metabolic syndrome, infectious and autoimmune diseases $(1,2)$. Vitamin $D$ receptors are present in hematopoietic cells and variety of tissues in the body (3). Vitamin D regulates various genes that responsible for cell proliferation by binding to the active vitamin $D$ receptor and inhibits the growth of cancer cells (4-6). Vitamin D deficiency may contribute to carcinogenesis by impairing these normal regulatory processes. In some studies reported that vitamin $D$ deficiency was associated with inferior event free survival and overall survival in patients with diffuse large B cell and T cell non-Hodgkin lymphoma and a worse outcome in patients with acute myeloid leukemia $(7,8)$.

Multiple myeloma (MM) is a non-curative hemalogical malignant disease and it originates from plasma cells. The patients with MM have some prognostic marker e.g; plasma cell labeling index, the presence of some cytogenetic abnormalities, gene expression profile, the stage of disease (9). Bone lesions occur in $80-90 \%$ of all cases with MM at the time of diagnosis and are among the most important causes of morbidity (10). Osteoclastmediated bone destruction increases and osteoblastic activity reduces significantly because of cytokines and chemokines that released from tumor cells and stroma cells in bone marrow (11). In addition, vitamin $D$ deficiency causes hyperparathyroidism that increases osteoclastic activity and decreases osteoblastic activity. Therefore vitamin D deficiency can contribute to the formation of bone lesions, risk of fall in MM. Bone lesions are often seen in the vertebral column, skull, ribs, pelvis and long bones and it may cause impairment in quality of life, neurological deficit, pathological fracture and hypercalcemia. Conventional radiography, computerized tomography (CT), magnetic resonance imaging (MRI) and positron emission tomography (PET) can be used to detect bone lesion. The aim of the present study was to verify the potential association between the level of 25 hydroxyvitamin D [25(OH)D] and lytic bone lesion, vertebral fracture, prognostic factors in MM.

\section{Materials and Methods}

In this study, we studied 184 newly diagnosed and treated MM patients at the Department of Hematology of the Atatürk University. Approval of the Atatürk University Ethics Committee was obtained for the study and informed consent was received from all participants (decision no: 31 , date: 27.02 .2020 ). The patients who measured the level of serum $25(\mathrm{OH}) \mathrm{D}$ at the time of admission were received in this study. The patients with chronic kidney failure and receving regular vitamin D supplements were excluded of this study.

We retrospectively examined the medical files of all cases and recorded sex, age, the levels of hemoglobin, serum creatine, blood urea nitrogen, total protein, albumin, calcium, globulin, serum immunoglobulin $(G, A, M), 25(O H) D$, the presence of lytic bone lesion and fracture, plasma cell rate in bone marrow, stage of disease. The presence of lytic bone lesion and fracture were evaluated by using conventional radiography and $\mathrm{CT} / \mathrm{MRI} / \mathrm{PET}-\mathrm{CT}$ findings. We used International Staging System (ISS) as the prognostic score. In this scoring system, if the albumin level $\geq 3.5$ $\mathrm{mg} / \mathrm{dL}$ and $\beta 2$ microglobulin level $<3.5 \mathrm{mg} / \mathrm{dL}$ is stage $1, \beta 2$ microglobulin level $\geq 5.5 \mathrm{mg} / \mathrm{dL}$ is stage 3 and patients who don't fulfill the stage 1 or 3 criteria are evaluated as stage 2 . 
Vitamin D level is often measured by automated immunoassays techniques (12). The serum level of 25(OH)D was measured using the CLIA method in the Siemens ADVIA Centaur XP device in our study. Vitamin $D$ sufficiency, insufficiency and deficiency were defined as $25(\mathrm{OH}) \mathrm{D}$ level of $30-100 \mathrm{ng} / \mathrm{mL}, 20-$ $29 \mathrm{ng} / \mathrm{mL}$, and less than $20 \mathrm{ng} / \mathrm{mL}$, respectively in Clinical Practice Guideline that it was published by the endocrine society's (13). In this study, the patients were divided into 3 groups according to this guideline; deficient $[25(\mathrm{OH}) \mathrm{D}<20 \mathrm{ng} / \mathrm{mL}]$, insufficient $[25(\mathrm{OH}) \mathrm{D}=$ $20-29 \mathrm{ng} / \mathrm{mL}$ ], and normal [25(OH)D $\geq 30 \mathrm{ng} / \mathrm{mL}$ ].

\section{Statistical Analysis}

Statistical evaluations were made by SPSS21 windows software (Armonk, NY: IBM Corp). Demographic variables were evaluated with simple descriptive analysis. We used independent t-test for determine difference between two goups if normal distribution was present, Mann-Whitney $U$ test was used if the group distribution was abnormal. One-way ANOVA was applied to test the mean differences between multiple groups. For all analyses, $p$-value $<0.05$ was considered to indicate statistical significance.

\section{Results}

The mean age of our cases was $68.74 \pm 10.47$ years and 55 (29.9\%) patients were female and 129 (70.1\%) patients were male. The median $25(\mathrm{OH}) \mathrm{D}$ level at the time of diagnosis, was $19.6 \pm 18.2 \mathrm{ng} / \mathrm{mL}$ (range $=3-71 \mathrm{ng} / \mathrm{mL}$ ) in 184 patients. There were 121 cases (65.8\%) with the 25(OH)D deficiency, 28 (15.2\%) cases with 25(OH)D insufficiency, and 35 (19\%) cases with $25(\mathrm{OH}) \mathrm{D}$ normal. Vitamin $\mathrm{D}$ deficiency increased with increasing age (Table 1).

Fifty seven (31\%) patients had stage 1, 53 (28.8\%) patients had stage 2,74 patients $(40.2 \%)$ had stage 3. The level of $25(\mathrm{OH}) \mathrm{D}$ was $22.95 \pm 21.22 \mathrm{ng} / \mathrm{mL}$ in patients with stage $1,20.72 \pm 16.21 \mathrm{ng} / \mathrm{mL}$ in cases with stage 2 , and $13.72 \pm 14.18 \mathrm{ng} / \mathrm{mL}$ in cases with stage 3 . As the disease stage increased, the $25(\mathrm{OH}) \mathrm{D}$ level decreased statistically significantly $(p=0.01)$.

Eighteen $(9.8 \%)$ of all patients had bone fracture and 105 of all patients (57.1\%) had lytic bone lesion. Bone fracture and the presence of lytic bone lesion were associated with $25(\mathrm{OH}) \mathrm{D}$ sufficiency and insufficiency (Table 2).

Laboratory findings of the patients were presented in Table 3. We didn't find a relationship between

\begin{tabular}{|c|c|c|c|c|}
\hline \multirow{2}{*}{ Vitamin D level } & \multicolumn{3}{|c|}{ Age } & \\
\hline & Mean \pm SD & Minumum & Maximum & p-value \\
\hline $25(\mathrm{OH}) \mathrm{D}$ deficiency $(n=121)$ & $73.14 \pm 8.9$ & 50 years & 88 years & \multirow{3}{*}{0.02} \\
\hline $25(\mathrm{OH}) \mathrm{D}$ insufficiency $(\mathrm{n}=28)$ & $68.39 \pm 9.04$ & 47 years & 78 years & \\
\hline Normal 25(OH)D level $(n=35)$ & $67.55 \pm 10.92$ & 24 years & 92 years & \\
\hline
\end{tabular}

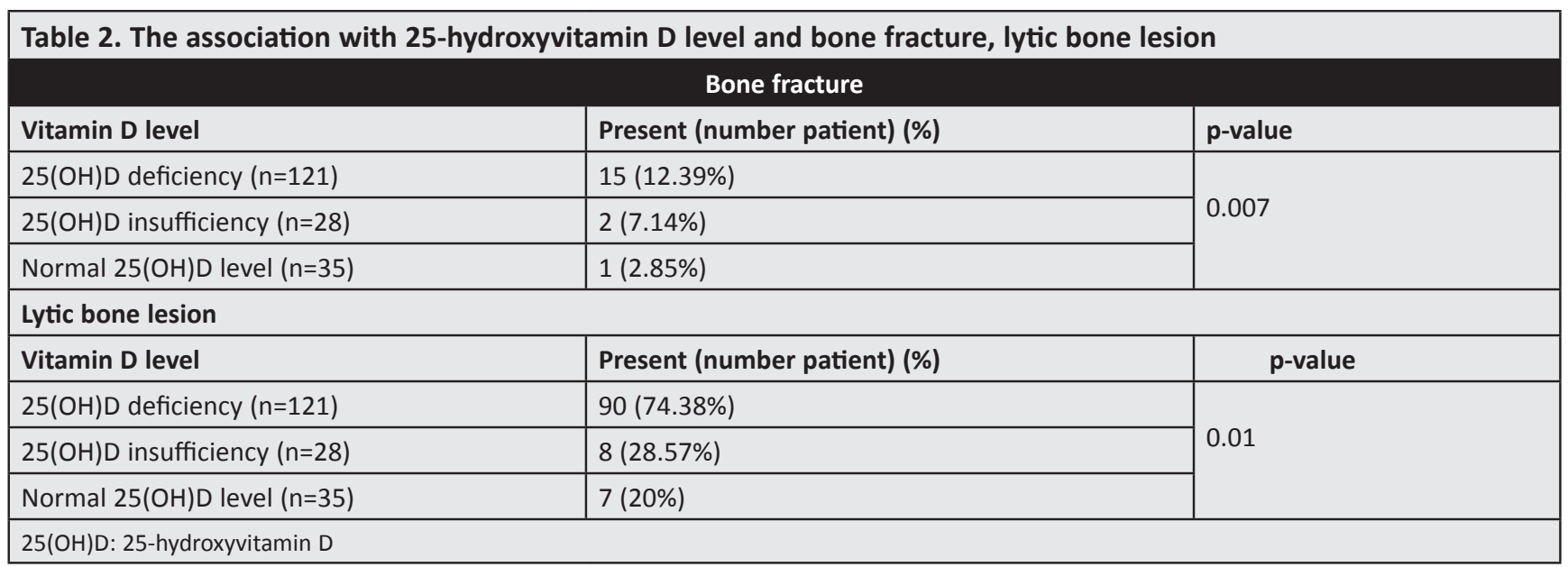


the levels of 25(OH)D and hemoglobin, calcium, sedimentation rate, albumin, globulin, creatine, $\beta 2$ microglobuline (Table 4). The statistically significant relationship was between the level of $25(\mathrm{OH}) \mathrm{D}$ and plasma cell count in bone marrow (Table 5).

\section{Discussion}

Vitamin D mainly provides the protection of calcium, phosphorus homeostasis and bone mineralization and its deficiency is a common public health problem around the world (14). Vitamin D deficiency causes rickets in children and osteomalacia in adults. But the consequences of its deficiency are not limited to rickets and osteomalacia. Several studies reported vitamin $D$ deficiency was associated with diabetes mellitus, hypertension, obesity, metabolic syndrome, cardiovascular disease, infectious and autoimmune diseases $(15,16)$. In addition, it is known that one of the causes of colon, breast and ovarian cancers is vitamin D deficiency $(17,18)$. In the northern states of the United States, prostate, breast

\begin{tabular}{|l|l|l|l|}
\hline Table 3. Laboratory findings of all the patients & Minimum & Maximum & Mean \\
\hline Variable & 10 & 65 & $30.8 \pm 11.76$ \\
\hline Plasma cell in bone marrow (\%) & 4.6 & 13.2 & $10.91 \pm 2.37$ \\
\hline Hemoglobin (g/dL) & 2 & 140 & $65.37 \pm 37.73$ \\
\hline Sedimentation rate & 6.1 & 15.5 & $8.45 \pm 2.14$ \\
\hline Total protein (g/dL) & 1.1 & 5.1 & $3.41 \pm 0.72$ \\
\hline Albumin (g/dL) & 1.8 & 10.7 & $5 \pm 2.42$ \\
\hline Globulin $(\mathrm{g} / \mathrm{dL})$ & 8.5 & 15.2 & $9.27 \pm 1.51$ \\
\hline Calcium $(\mathrm{mg} / \mathrm{dL})$ & 0.3 & 8.1 & $1.45 \pm 1.32$ \\
\hline Creatine $(\mathrm{mg} / \mathrm{dL})$ & 1.6 & 13.2 & $5.98 \pm 4.48$ \\
\hline$\beta 2$ microglobuline & 1.31 & 65.92 & $26.53 \pm 13.97$ \\
\hline Serum immunoglobulin G & 0.1 & 37 & $3.16 \pm 3.97$ \\
\hline Serum immunoglobulin A & 0.01 & 5.9 & $0.81 \pm 0.74$ \\
\hline Serum immunoglobulin M & & & \\
\hline
\end{tabular}

Table 4. The relationship with 25(OH)D level and laboratory findings

\begin{tabular}{|l|l|l|l|l|}
\hline Variable & $\mathbf{2 5}(\mathbf{O H}) \mathbf{D}$ deficiency & $\mathbf{2 5}(\mathbf{O H}) \mathbf{D}$ insufficiency & Normal 25(OH)D level & p-value \\
\hline Hemoglobin $(\mathrm{g} / \mathrm{dL})$ & $10.83 \pm 2.37$ & $11.28 \pm 2.01$ & $10.91 \pm 2.37$ & 0.66 \\
\hline Sedimentation rate & $65.09 \pm 36.44$ & $67.75 \pm 42.64$ & $64.40 \pm 39.10$ & 0.93 \\
\hline Albumin $(\mathrm{g} / \mathrm{dL})$ & $3.38 \pm 0.71$ & $3.52 \pm 0.83$ & $3.38 \pm 0.68$ & 0.64 \\
\hline Globulin $(\mathrm{g} / \mathrm{dL})$ & $4.98 \pm 2.46$ & $4.89 \pm 2.30$ & $5.19 \pm 2.42$ & 0.86 \\
\hline Calcium $(\mathrm{mg} / \mathrm{dL})$ & $9.34 \pm 1.48$ & $9.28 \pm 2.01$ & $9.03 \pm 1.08$ & 0.57 \\
\hline Creatine $(\mathrm{mg} / \mathrm{dL})$ & $1.32 \pm 1.21$ & $1.75 \pm 1.53$ & $1.67 \pm 1.46$ & 0.16 \\
\hline$\beta 2$ microglobuline & $5.90 \pm 4.38$ & $5.66 \pm 5.40$ & $6.52 \pm 4.12$ & 0.71 \\
\hline $25(\mathrm{OH}) \mathrm{D}:$ : 25-hydroxyvitamin D & & & \\
\hline
\end{tabular}

Table 5. The relationship with 25(level and the rate marrow $\mathrm{OH}$ )D of plasma cell in bone (\%)

\begin{tabular}{|c|c|c|c|c|}
\hline & \multicolumn{4}{|c|}{ Plasma cell rate in bone marrow (\%) } \\
\hline 25(OH)D level & Mean \pm SD & Minimum & Maximum & $\mathrm{p}$-value \\
\hline $25(\mathrm{OH}) \mathrm{D}$ deficiency $(n=121)$ & $68.39 \pm 9.04$ & 47 & 88 & \multirow{3}{*}{0.02} \\
\hline $25(\mathrm{OH}) \mathrm{D}$ insufficiency $(n=28)$ & $67.55 \pm 10.92$ & 24 & 92 & \\
\hline Normal 25(OH)D level $(n=35)$ & $35.75 \pm 13.53$ & 18 & 65 & \\
\hline
\end{tabular}


and colon cancer were more frequently than the sunnier states. Therefore, the relationship between vitamin D deficiency and incidence of cancer has been investigated in some studies (19-21). The altitude of Erzurum province, where the study is conducted, is 1,900 meters and the number of sunny days is low. Therefore, only $19 \%$ of our patients had normal vitamin D level.

Vitamin $D$ level is determined by measuring $25(\mathrm{OH}) \mathrm{D}$. The half-life of $1.25(\mathrm{OH}) \mathrm{D}_{2}$ is only 4 hours while the half-life of $25(\mathrm{OH}) \mathrm{D}$ is $2-3$ weeks and $25(\mathrm{OH}) \mathrm{D}$ circulates at a 1,000-fold higher concentration than $1,25(\mathrm{OH}) \mathrm{D}_{2}$. Therefore, we determined the patient's vitamin $D$ status by using the $25(\mathrm{OH}) \mathrm{D}$ level. The vitamin $D$ receptors are found in almost all cells in the human body. 25(OH)D affects angiogenesis by reducing the expression of vascular endothelial growth factor and interleukin 8. Vitamin D makes the antitumor effect by regulating proliferation, differentiation and apoptosis. We did not measure vitamin $D$ receptor level in this study.

Vitamin D deficiency is common in patients with MM $(22,23)$. Hudzik et al. (24) evaluated $675 \mathrm{MM}$ patients. They reported that $25(\mathrm{OH}) \mathrm{D}$ level was $<10$ $\mathrm{ng} / \mathrm{mL}$ in $52(7.7 \%)$ patients and it was $10-30 \mathrm{ng} / \mathrm{mL}$ in 394 (51\%) patients. Vitamin D deficiency was reported $16-37 \%$ of all patients with MM by Alvin C et al. (25). Graklanov et al. (26) evaluated 37 patients with newly diagnosed MM. They reported that 1 patient $(2.7 \%)$ had vitamin $D$ insufficiency (serum levels between $20-30 \mathrm{ng} / \mathrm{mL}$ ) and 36 patients $(97.3 \%)$ had vitamin $D$ deficiency (levels below $20 \mathrm{ng} / \mathrm{mL}$ ). Severe vitamin D deficiency $(<10 \mathrm{ng} / \mathrm{mL})$ was observed in $81 \%$ of all patients. Vitamin D deficiency was detected in $80.9 \%$ of all patients in our study. This may be explained by the lower exposure to sunlight due to high altitude and climate in the Erzurum. In addition, the fact that the people of Erzurum prefer the style of clothing that prevents the use of the sun can also contribute to this situation.

Vitamin D level was found significantly low in the patients with acute myeloid and lymphoblastic leukemias. It has been reported that vitamin $D$ deficiency to be associated with poor prognosis and worse response to treatment in patients with hematological malignancies $(27,28)$. Lauter et al. $(29)$ determined that $25(\mathrm{OH}) \mathrm{D}$ insufficiency $(<10 \mathrm{ng} / \mathrm{mL})$ was associated with elevated plasma cells count in the bone marrow. Gedik et al. (30) and Graklonav et al. (26) did not find a relationship between $25(\mathrm{OH}) \mathrm{D}$ level and ISS staging of MM. In addition Nath et al. (31) 41 patients with $\mathrm{MM}$ and they reported that there was no association between vitamin D status and stage of myeloma. But, it was reported that the prevalence of vitamin $D$ deficiency increased in parallel with ISS in another study (25). We detected that the patients with vitamin $\mathrm{D}$ deficiency and insufficiency had elevated plasma cell count in bone marrow and advanced stage disease. This two paramethers are negative prognostic factors in MM. Increased $\beta 2$ microglobuline level is also a poor prognostic marker. We didn't define a relationship between $\beta 2$ microglobuline level and vitamin D status. In addition, we could not evaluate the survival of patients due to lack of data.

Vitamin D deficiency was related to high C-reactive protein (CRP) and creatine levels and advanced stage disease in MM $(32,33)$. But we didn't find any significant correlation between vitamin $D$ status and serum creatine level. Alvin C et al. (25) examineted 148 patients with MM. They detected that the patients with vitamin D deficiency $[25(\mathrm{OH}) \mathrm{D}<20 \mathrm{ng} /$ $\mathrm{mL}$ ] had higher serum CRP, creatine levels and lower serum albumin level than patients without vitamin $D$ deficiency (25). But we didn't find any correlation between vitamin $D$ status and serum albumin, creatine levels.

Vitamin D deficiency can cause musculoskeletal pain, proximal muscle weakness, increased risk of falls. Low levels of vitamin 25(OH)D can cause secondary hyperparathyroidism and bone resorption via osteoclasts, which may accelerate osteopenia and osteoporosis in adults. Skeletal complications, such as lytic bone lesion, hypercalcemia, compression fracture are the main causes of morbidity in MM. Therefore, early diagnosis and treatment of vitamin $D$ deficiency may reduce skeletal complications. Alvin didn't find any correlation between low vitamin D level and skeletal morbidity. Badros et al. (33) evaluated $100 \mathrm{MM}$ patients and they reported that there was no significant correlation between vitamin $D$ status and presence of lytic bone disease and fracture. Nath et al. (31) reported that MM cases with vitamin D deficiency have higher skeletal morbidity, but this is not statistically significant ( $73 \%$ vs $50 \%, p=0.19$ ). But we defined that the lytic bone lesion and bone fracture were more common in patients with vitamin $D$ deficiency and insufficiency. 


\section{Conclusion}

Low vitamin $D$ level is important public health problem. Because it is associated with increased malignancy incidence and worse prognosis in patients with hematological and solid organ malignancies. Therefore treatment of vitamin $D$ deficiency may be reduce cancer devolopment and worse prognosis in patients with cancer. This hypothesis should be supported by studies involving more cases.

\section{Ethics}

Ethics Committee Approval: Approval of the Atatürk University Ethics Committee was obtained for the study (decision no: 31, date: 27.02.2020).

Informed Consent: Informed consent was received from all participants

Peer-review: Externally peer-reviewed.

\section{Authorship Contributions}

Concept: G.S., F.E., Design: G.S., F.E., Supervision: G.S., F.E., Fundings: G.S., Materials: G.S., Data Collection or Processing: G.S., F.E., Analysis or Interpretation: F.E., Literature Search: F.E., Writing: G.S., F.E., Critical Review: F.E.

Conflict of Interest: No conflict of interest was declared by the authors.

Financial Disclosure: The authors declared that this study received no financial support.

\section{References}

1. Pludowski P, Holick MF, Pilz S, Wagner CL, Hollis BW, Grant WB, et al. Vitamin $D$ effects on musculoskeletal health, immunity, autoimmunity, cardiovascular disease, cancer, fertility, pregnancy, dementia and mortality-a review of recent evidence. Autoimmun Rev 2013; 12: 976-89.

2. Gorle RM, Kumar MA, Ayyagari S. Effect of serum vitamin D deficiency in the prevalence of haematological malignancies. Int J Clin Biochem Res 2018; 5: 185-90.

3. Medrano M, Carrillo-Cruz E, Montero I, Perez-Simon JA. Vitamin D: Effect on Haematopoiesis and Immune System and Clinical Applications. Int J Mol Sci 2018; 19: 2663.

4. Manson JE, Mayne ST, Clinton SK. Vitamin D and prevention of cancer--ready for prime time? N Engl J Med 2011; 364: 1385-7.

5. Krishnan AV, Feldman D. Mechanisms of the anti-cancer and anti-inflammatory actions of vitamin D. Annu Rev Pharmacol Toxicol 2011; 51: 311-36.

6. Deeb KK, Trump DL, Johnson CS. Vitamin D signalling pathways in cancer: potential for anticancer therapeutics. Nat Rev Cancer 2007; 7: 684-700.

7. Drake MT, Maurer MJ, Link BK, Habermann TM, Ansell SM, Micallef IN, et al. Vitamin D insufficiency and prognosis in nonHodgkin's lymphoma. J Clin Oncol 2010; 28: 4191-8.
8. Lee HJ, Muindi JR, Tan W, Hu Q, Wang D, Liu S, et al. Low 25(OH) vitamin D3 levels are associated with adverse outcome in newly diagnosed, intensively treated adult acute myeloid leukemia. Cancer 2014; 120: 521-9.

9. Hanbali A, Hassanein M, Rasheed W, Aljurf M, Alsharif F. The Evolution of Prognostic Factors in Multiple Myeloma. Adv Hematol 2017; 2017: 4812637.

10. Terpos E, Dimopoulos MA. Myeloma bone disease: pathophysiology and management. Ann Oncol 2005; 16: 122331.

11. Croucher $\mathrm{PI}, \mathrm{Apperley} \mathrm{JF.} \mathrm{Bone} \mathrm{disease} \mathrm{in} \mathrm{multiple} \mathrm{myeloma.} \mathrm{Br} \mathrm{J}$ Haematol 1998; 103: 902-10.

12. Ong MW, Salota R, Reeman T, Lapsley M, Jones L. Artefactual $25-\mathrm{OH}$ vitamin $\mathrm{D}$ concentration in multiple myeloma. Ann Clin Biochem 2017; 54: 716-20.

13. Holick MF, Binkley NC, Bischoff-Ferrari HA, Gordon CM, Hanley DA, Heaney RP, et al. Evaluation, treatment, and prevention of vitamin D deficiency: an Endocrine Society clinical practice guideline. J Clin Endocrinol Metab 2011; 96: 1911-30.

14. Bringhurst FR, Demay MB, Kronenberg HM. Chapter 402: Bone and Mineral Metabolism in Health and Disease. In: Kasper DL, Braunwald E, Fauci AS, Hauser SL, Longo DL, Jameson JL, editors. Harrison's Principles of Internal Medicine, 16th ed. New York: MCGraw-Hill; 2005: 2238-86.

15. Holick MF. Vitamin D: a D-Lightful health perspective. Nutr Rev $2008 ; 66$ (10 Suppl 2): 182-94.

16. Hyppönen E, Boucher BJ, Berry DJ, Power C. 25-hydroxyvitamin D, IGF-1, and metabolic syndrome at 45 years of age: a crosssectional study in the 1958 British Birth Cohort. Diabetes 2008; 57: 298-305.

17. Garland CF, Gorham ED, Mohr SB, Grant WB, Giovannucci EL, Lipkin $M$, et al. Vitamin $D$ and prevention of breast cancer: pooled analysis. J Steroid Biochem Mol Biol 2007; 103: 708-11.

18. Giovannucci E. The epidemiology of vitamin D and cancer incidence and mortality: a review (United States). Cancer Causes Control 2005; 16: 83-95.

19. Gandini S, Boniol M, Haukka J, Byrnes G, Cox B, Sneyd $M J$, et al. Meta-analysis of observational studies of serum 25-hydroxyvitamin D levels and colorectal, breast and prostate cancer and colorectal adenoma. Int J Cancer 2011; 128: 1414-24.

20. Chandler PD, Buring JE, Manson JE, Giovannucci EL, Moorthy MV, Zhang S, et al. Circulating Vitamin D Levels and Risk of Colorectal Cancer in Women. Cancer Prev Res (Phila) 2015; 8: 675-82.

21. Zhang $H$, Zhang $H$, Wen $X$, Zhang $Y$, Wei $X$, Liu T. Vitamin $D$ Deficiency and Increased Risk of Bladder Carcinoma: A MetaAnalysis. Cell Physiol Biochem 2015; 37: 1686-92.

22. Burwick N. Vitamin D and plasma cell dyscrasias: reviewing the significance. Ann Hematol 2017; 96: 1271-7.

23. Maier GS, Horas K, Kurth AA, Lazovic D, Seeger JB, Maus U. Prevalence of Vitamin D Deficiency in Patients with Bone Metastases and Multiple Myeloma. Anticancer Res 2015; 35: 6281-5.

24. Hudzik S, Snoad B, Mousa L, Sborov DW, Williams N, Jones D, et al. The Majority of Myeloma Patients Are Vitamin D Deficient, Unrelated to Survival or Cytogenetics. Blood 2015; 126: 5336. 
25. Alvin C Ng, Kumar SK, Rajkumar SV, Drake MT. Impact of vitamin $D$ deficiency on the clinical presentation and prognosis of patients with newly diagnosed multiple myeloma. Am J Hematol 2009; 84: 397-400.

26. Graklanov V, Popov V, Raycheva R. Serum Levels of Vitamin D in Patients with Multiple Myeloma. Folia Med (Plovdiv) 2020; 62: 730-5.

27. Thomas $X$, Chelghoum $Y$, Fanari N, Cannas G. Serum 25-hydroxyvitamin $D$ levels are associated with prognosis in hematological malignancies. Hematology 2011; 16: 278-83.

28. Wang W, Li G, He X, Gao J, Wang R, Wang Y, et al. Serum 25-hydroxyvitamin $D$ levels and prognosis in hematological malignancies: a systematic review and meta-analysis. Cell Physiol Biochem 2015; 35: 1999-2005.

29. Lauter B, Schmidt-Wolf IG. Prevalence, Supplementation, and Impact of Vitamin D Deficiency in Multiple Myeloma Patients. Cancer Invest 2015; 33: 505-9.
30. Gedik H, Yokus O, Hilmi Dogu M, Aydinli F, Eren R, Altindal S. Vitamin $D$ deficiency and its effects on patients with multiple myeloma. Hematol Transfus Int J 2017; 5: 195-9.

31. Nath K, Ganeshalingam V, Ewart B, Heyer E, Watt K, Birchley $A$, et al. A retrospective analysis of the prevalence and clinical outcomes of vitamin $D$ deficiency in myeloma patients in tropical Australia. Support Care Cancer 2020; 28: 1249-54.

32. Diamond T, Golombick T, Manoharan A. Vitamin D status may effect the skeletal complications of multiple myeloma. Am J Hematol 2010; 85: 302-3.

33. Badros A, Goloubeva O, Terpos E, Milliron T, Baer MR, Streeten E. Prevalence and significance of vitamin $D$ deficiency in multiple myeloma patients. Br J Haematol 2008; 142: 492-4. 